\title{
Korea's Refugee Act: A Critical Evaluation under International Law
}

\author{
Andrew Wolman*
}

On December 29, 2011, the National Assembly of the Republic of Korea passed the Law on the Status and Treatment of Refugees, which went into effect on July 1, 2013. The law was the culmination of years of effort by the government, NGOs, UNHCR and the lawmakers. It has been widely praised by civil society groups in Korea. However, there has been little critical analysis of its provisions whether it will truly be a successful legislation. This research critically evaluates whether the new law is likely to promote Korean compliance with international legal standards, namely, the 1951 Refugee Convention and major human rights treaties. It finds that while the law represents a significant improvement over current practices, it possesses problematic provisions related to detention, refugee determination, economic and social rights of asylum-seekers, and the treatment of recognized refugees. This essay will conclude by highlighting four outstanding implementation questions that could impact compliance with international standards.

\section{Keywords}

Refugee Act, 1951 Refugee Convention, UNHCR, Refugee Rights, Asylum-Seekers

* Associate Professor at the Graduate School of International and Area Studies, Hankuk University of Foreign Studies. A.B.(Princeton), J.D.(NYU), LL.M.(GWU). He may be contacted at: amw247@yahoo.com / Address: 270 ImunDong, Dongdaemun-gu, Globeedorm, \#A806, Seoul 130-791 Korea. This article was supported by the 2012 Hankuk University of Foreign Studies Research Fund.

DOI: http://dx.doi.org/10.14330/jeail.2013.6.2.07 


\section{Introduction}

After years of intense discussion and consultations between lawmakers, the government, local civil society organizations and the local office of the United Nations High Commissioner on Refugees ("UNHCR"), the National Assembly of the Republic of Korea ${ }^{1}$ passed the Law on the Status and Treatment of Refugees (hereinafter Refugee Act) during the final legislative session of 2011. ${ }^{2}$ The Refugee Act, which finally went into effect on July 1, 2013, will give Korea the first separate refugee law in Asia. Many hope that it will usher in a more welcoming era for refugees in Korea. ${ }^{3}$

Although the Refugee Act has been generally praised by observers, there has been little critical analysis of its provisions or consideration of whether it will truly be successful in bringing Korea into compliance with its obligations under international refugee law and international human rights law. This essay will attempt to fill this gap by taking a closer examination of the provisions of the law, and assessing whether the law will lead to the effective fulfillment of Korea's international legal duties. This paper is divided into seven parts including short Introduction and Conclusion. After reviewing a brief history of the development of refugee policy in Korea in Part two, Part three will provide an overview of the new law that highlights positive advances over prior Korean practice. Part four will then discuss the improvements of the new law over prior practice. Part five consists of an evaluation of the Refugee Act's compliance with international norms in four key areas, while Part six will discuss the major unanswered questions that remain to be addressed once the act enters into force.

\section{A Brief History of Korean Refugee Policy}

In 1992, Korea ratified both the United Nations Convention relating to the Status of

The Republic of Korea will be referred to as 'Korea' for the sake of brevity.

Law No. 11298 (proclaimed Feb. 10, 2012, enforced July 1, 2013).

3 Chul Hyo Kim, A Step Forward to Refugee Protection? South Korea's New Refugee Act, 2 Oxford Monitor of Forced Migration 8 (2012). 
Refugees of 1951 (hereinafter Refugee Convention) ${ }^{4}$ and its 1967 Protocol. ${ }^{5}$ For much of the two decades following that ratification, however, Korea remained firmly on the sidelines of the international refugee regime. Although refugee protection provisions were integrated into the Immigration Control Act in 1993, ${ }^{6}$ the practical effect was so limited that no single refugee was recognized prior to the year 2001. Korea did begin to welcome large numbers of North Korean escapees during that period, but North Koreans are not considered eligible for refugee status under Korean law because North Korea is constitutionally deemed to be part of (South) Korean territory, and the escapees are therefore considered as Korean nationals with full rights as citizens once they reach the South. ${ }^{7}$

With the beginning of the new millennium, Korea made its first steps towards complying with its duties under the Refugee Convention and engaging with the international community on refugee matters. In 2000, Korea joined the UNHCR Executive Committee, where it has occupied a place ever since. A year later it recognized its first refugee and UNHCR opened up a branch office in Seoul. ${ }^{8}$ Meaningful progress was slow, however; between 2001 and 2008, only 101 refugees were recognized, out of a total of 2,072 applications. ${ }^{9}$ Korean refugee recognition procedures were frequently criticized as inadequate, by both domestic and international observers. ${ }^{10}$

Over the past few years, however, the Korean government has taken a renewed interest in refugee issues, due in part to the powerful advocacy work of a handful of recently formed local NGOs and the sustained attention of the Korean National Human Rights Commission, which has issued several recommendations aimed at

4 Signed on July 28, 1951, entered into force on Apr. 22, 1954. 189 U.N.T.S. 2545:150. The full text is available at http://www.ohchr.org/EN/ProfessionalInterest/Pages/StatusOfRefugees.aspx (last visited on Oct. 1, 2013). For details on the drafting history of the Refugee Convention, see A. Zimmermann et al. (eds.), The 1951 Convention Relating to the Status of Refugees and Its 1967 Protocol: A Commentary 37-74 (2011).

5 Signed on Jan. 31, 1967, 606 U.N.T.S. 8791:267, available at http://www.refworld.org/docid/3ae6b3ae4.html (last visited on Oct. 1, 2013).

6 Law No. 4592 (Dec. 10, 1993) (amended version of the Immigration Control Act, Law No. 1289 on Mar. 5, 1963).

7 See generally, Eric Yong Joong Lee, National and International Legal Concerns regarding Recent North Korean Escapees, 13 Int'L J. Ref. L 142 (2001).

8 Chan Un Park, Refugees and Korean Practices Thereof, 40 Kanagawa Hogaku 1, 4 (2007), available at http:// klibredb.lib.kanagawa-u.ac.jp/dspace/handle/10487/8203 (last visited on Oct. 27, 2013).

9 National Statistical Office of the Republic of Korea, Refugee Statistics, available at http://www.index.go.kr/egams/ stts/jsp/potal/cust/intro/information_main.jsp (last visited on Aug. 18, 2013). During this period, 63 additional applicants were permitted to stay in Korea with 'humanitarian status.' Id.

10 See Human Rights Council, Report of the Working Group on the Universal Periodic Review: Republic of Korea, U.N. Doc. A/HRC/8/40 (May 29, 2008), ๆ 44; Comm. on the Elimination of Racial Discrimination, Concluding Observations of the Committee on the Elimination of Racial Discrimination: Republic of Korea, U.N. Doc. CERD/C/ KOR/CO/14 (Aug. 17, 2007), ๆ 15. 
protecting the rights of refugees in Korea. ${ }^{11}$ In 2009, revisions to the Immigration Control Act came into effect that, inter alia, stipulated that refugees should be treated in line with the requirements of the Refugee Convention; ${ }^{12}$ allowed the Minister of Justice to grant a 'Humanitarian Stay' to applicants who did not fall under the refugee definition; ${ }^{13}$ permitted applicants to apply for a temporary work permit if no decision was made within one year of their application, ${ }^{14}$ and permitted the Minister of Justice to establish facilities for refugees and asylum-seekers. ${ }^{15}$ In 2010, the first refugee was naturalized as a Korean citizen. ${ }^{16}$ There has also been a significant increase in the amount of Korean contributions to UNHRC, from USD 2,198,037 in 2007 to USD 4,696,905 in 2011. ${ }^{17}$ The most important development has been the longawaited passage of the Refugee Act, which provides a significantly updated legal framework for addressing refugee matters in Korea.

\section{Overview of the Refugee Act}

The Refugee Act is composed of six chapters with 47 articles. ${ }^{18}$ After an initial chapter of general articles, chapter two of the Act addresses refugee status application and determination. It details the determination process and introduces a so-called fast track process, that allows the Minister of Justice to "omit part of the determination process" in cases of claimant untruthfulness, reapplication without material change

11 The National Human Rights Commission made recommendations on the overall improvement of refugee rights in 2006; in 2008 recommended the protection of rights for those in humanitarian protection status, and in 2011 recommended that asylum-seekers awaiting final decision of their appeal be given permission to seek employment. Dong Hyuk Choi, Migration Director of the National Human Rights Commission of Korea, Speech before the International Conference on Refugee Rights, Seoul, Korea (Aug. 21, 2012).

12 Law No. 9142, arts. 76-78(1) (Dec. 19, 2008) (amending the Immigration Control Act, Law No. 1289 (Mar. 5, 1963)).

13 Id. arts. 76-78(2).

14 Id. art. 76-78(3).

15 Id. arts. 76-79. In line with this provision, a new reception center is under construction on Yeongjong-do Island, near Incheon International Airport. It is currently slated to begin operation in June 2013. Telephone Interview with Jae Hyun Park, Deputy Director of Nationality and Refugee Division, Ministry of Justice of Korea (Oct. 15, 2012).

16 Jong Chul Kim, Refugees, in Key Migration Issues for the Republic of Korea 183, 195 (Julia Jiwon Shin ed. 2011).

17 UNHCR, Rep. of Korea Profile, www.unher.org/pages/49e489036.html (last visited on Aug. 18, 2013). Private sector contributions to UNHCR from Korea have increased even more dramatically during this time, from USD 20,686 in 2007 to USD 1,329,357 in 2011. Id.

18 See The Refugee Act (An unofficial English translation of by UNHCR), available at http://www.refworld.org/ docid/4fd5cd5a2.html (last visited on Aug. 18, 2013). 
in circumstances, or where the asylum claim comes after a year when the claimant's visa is about to expire, or in order to delay implementation of a removal order. ${ }^{19}$ Several provisions then describe the factual investigation procedures and detail the rights of applicants to legal aid; the presence of a trusted individual at interviews; the use of an interpreter, and access to documents related to their case. ${ }^{20}$ There is protection for the confidentiality of the proceedings. ${ }^{21}$ The refugee recognition process is subject to a six month time limit, extendable an additional six month if there are unavoidable circumstances. ${ }^{22}$

Following these clauses, the Act outlines the appeals process. Denials, cancellations and withdrawals of refugee status may be appealed to the Minister of Justice within 30 days. ${ }^{23}$ The Minister of Justice will then without delay refer the case to the Refugee Committee, which will conduct a factual investigation, either directly or through refugee research officers. After this review, the Ministry of Justice must make a decision within six months of receipt of the appeal, but if this is impossible due to unavoidable circumstances, the deadline can be extended an additional six months. Finally, Article 24 states that the Minister of Justice may permit the resettlement of refugees after review by the Foreigners' Policy Committee. ${ }^{24}$

Chapter three of the Refugee Act addresses the structure and operation of the Refugee Committee (hereinafter the Committee), which is tasked with reviewing appeals from asylum denials or cancellations. ${ }^{25}$ The Committee consists of up to fifteen members, appointed by the Ministry of Justice, who will be either licensed lawyers; academics with titles of associate professor or higher; members of the government who at the fourth level or above who are or were in charge of refugee matters; or persons with other professional experience or expertise in refugee matters. ${ }^{26}$ UNHCR is nor represented on the Committee, but is permitted to interview an asylum-seeker and submit opinions in asylum applications or appeals. ${ }^{27}$

Chapter four deals with the treatment of recognized refugees and others. The first section provides that recognized refugees must be "treated in accordance with

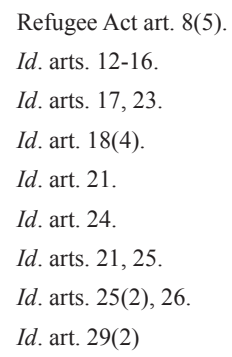


the Refugee Convention notwithstanding other laws and regulations." ${ }^{28}$ It then lists explicit rights to social security at the same level as Korean nationals; rights to support under Articles 7 to 15 of the National Basic Living Security Act; and rights to primary and secondary education at the same level as Korean nationals. ${ }^{29}$ Additional provisions allow for (but do not require) the provision of social integration programs and the recognition of academic and professional qualifications. ${ }^{30}$ Family unity is provided for in Article 37, which, with certain exceptions, requires the government to permit entry into the country for any spouse or minor children. ${ }^{31}$ The second section of this Chapter simply states that the Minister of Justice "may permit a humanitarian status holder to engage in wage-earning employment." ${ }^{\text {" }}$ The third section addresses the treatment of refugee status applicants. It states that the Minister of Justice may provide living and other expenses; may establish and operate residential facilities; may provide health services, and may provide applicants and their families with primary and secondary education at the same level as Korean nationals. ${ }^{33}$ These benefits may be partly or wholly limited for, among others, applicants who are administratively appealing or litigating a denial of refugee status. ${ }^{34}$

\section{Improvements over Prior Practice}

In many ways, the Refugee Act presents a clear improvement over present Korean practice. As a starting point, the Refugee Act allows asylum claims to be filed from ports of entry. ${ }^{35}$ This seemingly basic provision represents a change from current practice, which prohibits the filing of claims at airports. ${ }^{36}$ For the first time, the Refugee Act provides explicit rights to legal assistance and translated documents, guaranteed access to information for applicants, and explicit protections of confidentiality. The six month time limit for refugee determinations should speed up

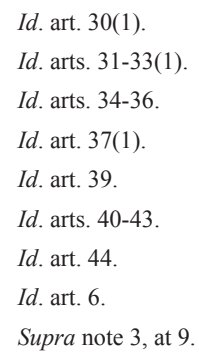


the process compared to past years, when two or three year waits were common. ${ }^{37}$ Work permits for asylum-seekers will be discretionary for asylum-seekers after six months, rather than one year, as in the current regulations. ${ }^{38}$ In general, the clauses allowing the discretionary provision of social benefits in the Refugee Act may be inadequate, but still represent an improvement over the current scheme, where such provisions are absent altogether (although refugees and asylum-seekers are sometimes able to receive benefits pursuant to other laws).

Perhaps the most highly anticipated new provision is the authorization of resettlement, as anticipated by Article 24 of the new law. ${ }^{39}$ While the number of resettled refugees is unlikely be high in coming years, Korea's decision to consider a program is significant. To date, Japan is the only country in Asia to have resettled refugees, so if Korea follows suit it will send a powerful signal to other Asian nations that resettlement plays an important role in a country's refugee policy.

\section{Does the Refugee Act Comply with International Standard?}

Korea is subject to a number of binding international legal laws in its treatment of asylum-seekers and refugees. The most important of these is the Refugee Convention. However, it is equally bound by the major human rights treaties, such as the International Covenant on Civil and Political Rights ("ICCPR") ${ }^{40}$ and International Covenant on Economic and Social Rights ("ICESCR"), both of which Korea acceded to in 1990. While these human rights treaties do not focus on refugees, they do provide refugees with a number of important rights, as has been recognized by their respective treaty bodies and other commentators.

Although the Refugee Act was drafted in consultation with civil society groups and with significant input from UNHCR, it does not necessarily mean that the final bill in all ways complies with these international obligations. In fact, at the end of

37 Advocates for Public Interest Law, NGO Submission to the Universal Public Review for the Republic of Korea: $14^{\text {th }}$ Session of the UPR Working Group (Apr. 23, 2012), ๆ 3, available at http://lib.ohchr.org/HRBodies/UPR/ Documents/Session14/KR/JS2_UPR_KOR_S14_2012_JointSubmission2_E.pdf (last visited on Oct. 19, 2013).

38 Immigration Control Act arts. 76-78(3).

39 Refugee Act art. 24.

40 Signed on Dec. 16, 1966, entered into force on Mar. 23, 1976, G.A. Res. 2200(XXI), U.N. Doc. A/6316. 999 U.N.T.S. 14668:171.

41 Signed on Dec. 16, 1966, entered into force on Jan. 3, 1976, G.A. Res. 2200A(XXI), U.N. Doc. A/6316. 993 U.N.T.S. 14531:3. 
the day, the Refugee Act was a political compromise that rejected many suggestions from UNHCR and others. In this section, the author will evaluate the Refugee Act's compliance with international standard in four key areas: detention; refugee determination and appeals procedures; rights of asylum-seekers; and treatment of recognized refugees and individuals with humanitarian status.

\section{A. Detention}

The use of detention in the refugee context is almost always troublesome. As a general rule, Article 12(1) of ICCPR states that: "Everyone lawfully within the territory of a state shall, within that territory, have the right of liberty of movement and freedom to choose his residence." ${ }^{" 2}$ UNHCR has stated that "as a general principle, asylum-seekers should not be detained." ${ }^{43}$ There are, however, a few exceptions to this rule. According to ExCom Conclusion No. 44, detention of asylum-seekers is only permissible in the following condition: where the asylum seeker's identity is undetermined or in dispute; to determine the elements on which the asylum claim is based (not extending to the merits of the claim); in cases where the asylum seeker has destroyed their identity documents or used fraudulent documents, or to protect national security and public order. ${ }^{44}$

The Refugee Act only explicitly allows for detention in order to determine identity. Such detention is limited in duration to ten days, with a possible extension of up to ten more days where verification of identity is delayed due to unavoidable circumstances. ${ }^{45}$ The maximum length of time is consistent with international standard, although some countries permit a much shorter period of detention in order to determine identity. ${ }^{46}$ Thus, as long as procedural safeguards are in place, conditions of detention are adequate, and sufficient allowances are made for particularly vulnerable asylum-seekers such as children, this clause would not violate international law.

There are, however, more serious questions regarding the potential for detention

42 ICCPR art. 12(1).

43 Office of the United Nations High Commissioner for Refugees, UNHCR's Guidelines on Applicable Criteria and Standards Relating to the Detention of Asylum-Seekers 3 (Feb. 1999).

44 Rep. of the UNHCR Exec. Comm., 37th Sess., Conclusions on Detention of Refugees and Asylum-Seekers, U.N. Doc. A/41/12/Add.1 (Jan. 13, 1987) ExCom Conclusions are not formally binding, but "constitute expressions of opinion which are broadly representative of the views of the international community." See also UNHCR, Conclusions on International Protection, available at http://www.unhcr.org/pages/49e6e6dd6.html (last visited on Aug. 18, 2013).

45 Refugee Act art. 20.

46 See, e.g., Aliens Act 2005, ch. 10, $\$ 4$ (Sweden) (48 hour detention limit to investigate identity of a foreign national); Law on Foreigners, art. 73 (Switzerland) (three day limit to determine identity). 
in airports. Article 6(3) of the Act states that, for applications at a port of entry, the Minister of Justice "shall decide within seven days of the submission of a refugee status application whether to refer the application to the refugee status determination procedure." ${ }^{47}$ This appears to create a loophole in the process, whereby airport immigration authorities would in practice be able to detain individuals for up to seven days before deciding whether or not to commence a refugee status determination. The Refugee Act does not provide for any protections or access to assistance for individuals in this position, which runs contrary to international standard. ${ }^{48}$ In addition, there is neither guidance as to when the Ministry of Justice is permitted to decide not to refer an asylum claim for determination, nor realistic recourse or appeals process to this decision, given that it seems likely to result in the applicant's immediate deportation. Therefore, Article 6(3) has the potential to violate not only the freedom of movement, but also basic due process principle, as laid down at Article 9(4) of ICCPR, which states that: "Anyone who is deprived of his liberty by arrest or detention shall be entitled to take proceedings before a court, in order that court may decide without delay on the lawfulness of his detention and order his release if the detention is not lawful." ${ }^{49}$

\section{B. Refugee Determination Procedure}

An effective determination and appeals procedure is necessary for a country to fulfill the Refugee Convention's non-refoulement obligation. ${ }^{50}$ Detailed requirements are not contained in the Convention itself, although the UNHCR Executive Committee has issued some recommendations on the subject. In addition, some claim that Article 14 of ICCPR imposes procedural requirements on the determination process. ${ }^{51}$

While the refugee determination procedure in the Refugee Act is in most ways consistent with international standard, there are a few provisions questionable. E.g., Article 18 of the Refugee Act obliges the Minister of Justice to recognize an applicant

47 Refugee Act art. 6(3).

48 See, e.g., Global Consultations on International Protection/Third Track: Asylum Processes (Fair and Efficient Asylum Procedures), U.N. Doc. EC/GC/01/12 (May 31, 2001), ๆ 23 ("Access to legal advice, to UNHCR and to non-governmental organizations working on behalf of UNHCR is also critical ... in an airport transit zone.").

49 ICCPR art. 9(4). In the refugee context, this principle has been emphasized but the UNHCR Executive Committee, which has stated that "detention measures taken in respect of refugees and asylum-seekers should be subject to judicial or administrative review." Conclusions on Detention of Refugees and Asylum-Seekers, supra note 44.

50 Refugee Convention art. 33. For details, see UNHCR High Commissioner for Refugees, Handbook on Procedures and Criteria for Determining Refugee Status under the 1951 Convention and the 1967 Protocol relating to the Status of Refugees (Dec. 2011), 189 (hereinafter UNHCR Handbook), available at http://www.refworld.org/ docid/4f33c8d92.html; G. Goodwin-Gill \& J. McAdam, The Refugee in International Law 201 (2007).

51 G. Heckman, Canada's Refugee Status Determination System and the International Norm of Independence, 25 Refuge 79, 94 (2008). 
as a refugee if the refugee status application "has merit. ${ }^{, 52}$ UNHCR commented that it would have been preferable to recognize any person who is determined to be a refugee pursuant to the definition in the Refugee Convention. ${ }^{53}$ The existing terminology should effectively lead to much the same conclusion, however, as merit will presumably be judged according to the refugee definition in Article 2 of the Refugee Act.

As the UNHCR Executive Committee has emphasized, the provision of interpretation and translation services should be considered a basic requirement in order to properly determine refugee status. ${ }^{54}$ This is especially true in Korea, as very few asylum-seekers will speak Korean. The Refugee Act provides for translation and interpretation during interviews in Articles 14 and 15. However, there are no requirements that denial notices must be translated into a language that the applicant understands. This could present a problem because international law on refugee (and the Refugee Act) anticipate an appellate process for refugee denials, but the availability of an appeal could be practically limited if claimants cannot understand the reasons for denial of refugee status. ${ }^{55}$

Perhaps the most problematic provision is the "fast track procedure," which was inserted into the Refugee Act at the last minute and without consultation with other stakeholders. ${ }^{57}$ This provision allows the Minister of Justice to "omit part of the determination process" in three circumstances, namely, where: (1) the asylum seeker was untruthful or concealed facts in their application; (2) re-applied for refugee status without experiencing a material change in circumstances; or (3) filed an application after staying in Korea for one year or longer when the expiration of his or her sojourn period was imminent, or who filed for the purpose of delaying the enforcement of a removal order. ${ }^{58}$ Accelerated determination procedures create a danger of improper denial and violation of the non-refoulement obligation, particularly where, as is the case here, there is no guidance as to how exactly the procedure will be shortened. E.g., Article 8(5) leaves open the possibility of omission of the interview or other essential elements of the process.

52 Refugee Act art. 18.

53 UNHCR, UNHCR's Comments on the 2009 Draft Bill on Refugee Status Determination and Treatment of Refugees and Others (June 15, 2009), at 15 (hereinafter UNHCR Comments), available at http:/www.refworld.org/ docid/4a8d58092.html (last visited on Oct. 19, 2013).

54 UNHCR Handbook, ๆ 192(iv).

55 Id. at $192(\mathrm{vi})$.

56 Refugee Act art. 8(5).

57 Supra note 3, at 9.

58 Refugee Act art. 8(5). 
Accelerated procedures are not always objectionable; they exist in many other nations' legislations. ${ }^{59}$ However, such procedures are only permitted in certain very narrow circumstances. According to UNHCR Executive Committee Conclusion No. 30, accelerated procedures are appropriate only for cases that are 'clearly abusive' or 'manifestly unfounded. ${ }^{60}$ Article 8(5) of the Refugee Act, however, goes far beyond such chases, and seems likely to eventually lead to false denials, thus violating Korea's non-refoulement obligations, which apply equally to all applicants, even those that may have lied or waited until they are in danger of deportation before applying for asylum. ${ }^{61}$

\section{Economic and Social Rights of Asylum-Seekers}

Both ICESCR and the Refugee Convention mandate that parties must provide for the basic economic and social rights of asylum-seekers. ICESCR protects, inter alia, the right to work; right to social security; right to adequate food, clothes and housing, and right to health. ${ }^{62}$ States may not discriminate them based on nationality in the provision of such rights. ${ }^{63}$ Meanwhile, Articles 20-24 of the Refugee Convention outline the basic welfare rights, most notably that refugees should be given: as favorable treatment as possible, and in any case no less favorable than similarly situated aliens, with regard to housing; the same treatment as nationals with respect to elementary education; the same treatment as nationals with respect to public relief and assistance, and the same treatment as nationals with respect to labor legislation and social security. ${ }^{64}$ It should be stressed that refugee status adheres under international law as soon as an individual fulfills the criteria in the Refugee Convention, which necessarily occurs prior to State determination. ${ }^{65}$ Thus, in order

59 See generally Accelerated asylum procedures in Council of Europe member states, Council of Europe, Parliamentary Assembly Resolution 1471 (Oct. 7, 2005), available at http://assembly.coe.int/Mainf.asp?link=/ Documents/AdoptedText/ta05/ERES1471.htm\#_ftn1 (last visited on Oct. 19, 2013).

60 Rep. of the UNHCR Exec. Comm., 37th Sess., Conclusions on the Problem of Manifestly Unfounded or Abusive Applications for Refugee Status or Asylum, U.N. Doc. A/38/12/Add.1 (Nov. 8, 1983). See J. Moore, Restoring the Humanitarian Character of U.S. Refugee Law Lessons from the International Community, 15 BERKELEY J. INT'L L. 56 (1997), available at http://scholarship.law.berkeley.edu/cgi/viewcontent.cgi?article=1157\&context=bjil (last visited on Oct. 19, 2013).

61 In fact, it is quite common and understandable for genuine refugees to wait until their work or other visa is near expiration before taking the step of applying for asylum. There are also understandable reasons why some refugees might not always tell the truth, including worries about their personal security and the effect of traumatic experiences.

62 ICESCR arts. $6,9,11 \& 12$.

$63 I d$. art. 2(2). Developing countries may have certain exceptions from this rule, but this is not applicable to Korea. Id. art. 2(3).

64 Refugee Convention arts. 21-24.

65 UNHCR Handbook, at 28. 
to fully comply with the Refugee Convention, the aforementioned rights must be protected for asylum-seekers as well as recognized refugees. ${ }^{66}$

While the Refugee Act may be an improvement over current practice in that respect, it still falls well below international standards. In large part, this is due to the discretionary nature of the Refugee Act's various rights provisions as follows: Article 40 provides that the Minister of Justice may provide living and other expenses as determined by Presidential Decree; Article 41 states that the Minister of Justice may establish and operate residential facilities as determined by Presidential Decree; Article 42 states that the Minister of Justice may provide health services as determined by Presidential Decree; and Article 43 specifies that refugee status applicants and their families may receive primary and secondary education at the same level as Korean nationals. ${ }^{67}$ Should these benefits be denied, Korea will be out of compliance with both ICESCR and the Refugee Convention. Even these weak provisions are further limited by Article 44, which states that the preceding benefits may be partly or wholly limited by Presidential Decree for, among others, applicants who are administratively appealing or litigating a denial of refugee status. ${ }^{68}$ This provision, in addition to threatening the economic and social rights of asylumseekers, can also negate the possibility of appealing a denial of asylum, if an asylumseeker would have no means of surviving while an appeal is heard.

While the weakness of provisions on the economic and social rights of asylumseekers in Korea's new legislation is troubling, it should be pointed out that other developed countries have also been criticized for insufficiently providing for the welfare of asylum-seekers. In the European Union, e.g., conditions for asylum seekers are currently regulated by the 2003 Reception Conditions Directive, ${ }^{69}$ although an amended directive is in the process of being adopted. ${ }^{70}$ The current Reception Conditions Directive provides inter alia that Member States "shall make provisions on material reception conditions to ensure a standard of living adequate for the health of applicants and capable of ensuring their subsistence." ${ }^{\prime 1}$ Various member States have been strongly criticized for not fulfilling these terms, however, most notably Greece, where asylum-seekers have in recent years endured UNHCR, Note on International Protection, UN Doc. A/AC.96/815 (1993), ๆ
org/type,UNHCRNOTES,,,3ae68d5d10,0.html (last visited on Oct. 19, 2013).

67 Refugee Act arts. 40-42. [Emphasis added]

68 Id. art. 44.

69 Council Directive 2003/9/EC Laying Down Minimum Standards for the Reception of Asylum Seekers, 2003 O.J. (L 31) 18, available at http://eur-lex.europa.eu/LexUriServ/LexUriServ.do?uri=OJ:L:2003:031:0018:0025:EN:PDF (last visited on Oct. 27, 2013).

70 Reception Conditions for Asylum Seekers: New Rules Agreed, EU Focus 2012, 302, 3-4.

71 Supra note 69, art. 13. 
widespread destitution, homelessness and lack of medical care despite their legal right to adequate material conditions in reception centers and free medical treatment, employment and education. ${ }^{72}$ Meanwhile, in the United States, which has not ratified ICESCR, welfare and public benefits are only given to 'qualified aliens,' defined as aliens who are granted asylum or refugees who are admitted to the United States. ${ }^{73}$ Many asylum-seekers in the United States are in fact subject to detention, sometimes for months or years at a time. ${ }^{74}$

Perhaps the biggest concern of asylum applicants is whether they will either have the right to work or be able to benefit from support from the government. Unfortunately, the Refugee Act does not assure either of these. While Article 40 of the Refugee Act provides that the government "may provide living and other expenses" and may permit an applicant to work after six months has elapsed since the application, neither of these are mandatory. ${ }^{75}$ If the Korean government exercise its discretion to deny either financial support or a work permit, it is likely to violate binding obligations the right to work provision of ICESCR, ${ }^{76}$ as well as the mandate to "recognize the right of everyone to an adequate standard of living for himself and his family." ${ }^{77}$

\section{Treatment of Recognized Refugees and Individuals with Hu- manitarian Status}

Many of the rights that refugees are entitled to under the Refugee Convention are left out of the Refugee Act even for recognized refugees. There are no provisions on the right to own property, freedom of association, equal treatment with nationals regarding housing, or freedom of movement which have been protected by the Refugee Convention. ${ }^{78}$ Some of these issues are addressed elsewhere in Korean laws of general applicability, but their inclusion in the Refugee Act would have nevertheless helped provide a stronger bulwark against discrimination.

Nor is there any provision on naturalization, despite Korea's obligations

72 Amnesty International, The Dublin II Trap 35-41 (Mar. 2010), available at http://www.amnesty.org/en/library/info/ EUR25/001/2010/en (last visited Aug. 22, 2013).

73 B. Ugarkovic, A Comparative Study of Social and Economic Rights of Asylum Seekers and Refugees in the United States and United Kingdom, 32 GA. J. InT'L \& Comp. L. 539, 552 (2004) (citing 8 U.S.C. § 1641(b)(2)-(3) (2000)).

74 Human Rights First, U.S. Detention of Asylum Seekers: Seeking Protection, Finding Prison (2009), 16, available at http://www.humanrightsfirst.org/wp-content/uploads/pdf/090429-RP-hrf-asylum-detention-report.pdf (last visited on Oct. 1, 2013).

75 Refugee Act art. 40.

76 ICESCR art. 6

77 Id. art. 11.

78 Refugee Convention arts. 13, 15, $21 \& 26$. 
under Article 34 of the Refugee Convention to "make every effort to expedite naturalization proceedings and to reduce as far as possible the charges and costs of such proceedings. ${ }^{79}$ An earlier draft of the Refugee Act dealt with that obligation by stating that recognized refugees who had lived in Korea for over three years with a permanent address could be naturalized. ${ }^{80}$ This provision was omitted from the final language of the Refugee Act.

While non-refugees are not protected by the Refugee Convention, they still are entitled to rights under international human rights treaties. Thus, it is quite concerning that the Refugee Act gives the government discretion to grant work permits to individuals with humanitarian status. It does not, however, provide any other rights or benefits. ${ }^{81}$ In fact, earlier drafts of the bill did contain such protections; UNHCR in its comments "applaud[ed] the granting of the rights refugees have to individuals with humanitarian status." ${ }^{82}$ The excision of these clauses creates the possibility of violations of various basic economic and social rights, should they be discriminated against in terms of social protection, health care, educational or other critical services.

\section{Outstanding Implementation Questions}

When considering the potential compliance of the Refugee Act with international standards, four broad questions regarding implementation remain. The first question is how the Korean government will exercise the considerable discretion granted to it in the Refugee Act. As previously noted, the government has maintained discretion to award or deny work permits, living expenses, medical and residential services to asylum-seekers under Articles 40-42 of the Refugee Act. Work permits for humanitarian status holders are discretionary under Article 49. Should these be denied, Korea will likely be in breach of its obligations under ICESCR and the Refugee Convention. Additional guidance on these matters should be forthcoming when the Presidential Decree on enforcement of the Refugee Act is issued by the Ministry of Justice. ${ }^{83}$

79 Id. art. 34.

80 UNHCR Comments, at 31.

81 Refugee Act art. 39.

82 UNHCR Comments, at 31.

83 This decree will be issued in July 2013. Telephone Interview with Jae Hyun Park, supra note 15. 
The second question is whether the new law will lead to a general increase in refugee recognition rates. If the Ministry of Justice and the Korean court system adopt an overly suspicious attitude toward asylum claimants, then the nonrefoulement obligation may be breached even if the Refugee Act itself is seemingly adequate. Of course, it is impossible to judge what an appropriate refugee recognition rate would be, as such rates vary widely around the world ${ }^{84}$ However, Korea's recognition rate is by any standard quite low: only 89 individuals among 1,434 refugee claims were granted refugee status during the period of 2010-2011, with 59 others given supplementary protection. ${ }^{85}$ By contrast, the global average refugee recognition rate was $30 \%$ in 2011, according to UNHCR (38\% including supplementary protection). ${ }^{86}$ There are reasons to hope that the passage of the Refugee Act will help increase that rate. For one thing, the newly formed Refugee Committee and its Refugee Research Officers are likely to have more expertise in refugee issues than their current counterparts, which could help them to recognize valid claims. ${ }^{87}$ Also, increased provision of translators and legal aid could help asylum-seekers to effectively make their case. Finally, Article 9, which specifies that the Minister of Justice shall "make all efforts to collect evidence favorable to a refugee status applicant and shall use such evidence in the determination process" may spur a shift within the Ministry of Justice towards a more welcoming stance, although that is far from assured. ${ }^{88}$

The third question regarding the new regime is whether the law will be applied fairly and equally for Chinese asylum-seekers. Korea should be a natural destination for Chinese nationals fleeing persecution, given the two countries' geographical proximity and cultural similarities. However, the Ministry of Justice has yet to recognize a single refugee from China through its refugee determination process. ${ }^{89}$ As of the end of 2011, Korea had granted asylum to six Chinese nationals (out of 356 applicants during that period), but each of these resulted from either the Seoul Administrative Court or Korean Supreme Court overturning asylum denials, rather than a positive initial determination. ${ }^{90}$ By contrast, the global total recognition rate

84 UNHCR, UNHCR Global Trends 201128 (2012), available at http://www.unhcr.org/4fd6f87f9.html (last visited on Oct. 19, 2013).

85 National Statistical Office of the Republic of Korea, supra note 9.

86 Supra note 84 . This figure includes both UNHCR and State asylum procedures.

87 The expertise of the current immigration offices in charge of making refugee determinations has been questioned. See, e.g., Kim, supra note 16, at 196.

88 Refugee Act art. 9.

89 Telephone Interview with Jae Hyun Park, supra note 15.

90 National Statistical Office of the Republic of Korea, supra note 9. An additional 15 Chinese nationals were granted humanitarian status during that period. $I d$. 
(including both refugee status and supplementary protection) for Chinese nationals was $56 \%$ in $2011 .^{91}$

Unsurprisingly, this trend has led Chinese asylum claims in Korea to slow to a trickle. In 2010 and 2011, a total of only fifteen asylum claims were filed in Korea by Chinese nationals, ${ }^{92}$ a tiny fraction of the 46,000 claims made by Chinese nationals worldwide in those two years. ${ }^{93}$ Although officials would be reluctant to admit such considerations, observers have noted that Korean officials may be reluctant to recognize Chinese refugees out of fear - whether justified or not - of harming diplomatic relations between the two countries. ${ }^{94}$ While this political dynamic is unlikely to be affected by the passage of the Refugee Act, it would nevertheless be hard to argue that Korea is fulfilling its non-refoulement obligation if the Ministry of Justice continues its policy of uniformly rejecting Chinese applicants.

The final question is whether the new reception center that is being constructed will be managed appropriately so as to protect the rights of asylum-seekers. To be sure, there is nothing at this point to indicate that this center will be a negative development. They hope that the center will provide asylum claimants with a supporting environment for, needed services, and assist in their integration into the community. However, there are serious worries about the center from domestic civil society organizations, who have criticized the center for being isolated from Seoul and work opportunities. ${ }^{95}$ Others have stressed the need to ensure freedom of movement for asylum-seekers staying there. ${ }^{96}$

91 Supra note 84.

92 National Statistical Office of the Republic of Korea, supra note 9.

93 UNHCR, Asylum Levels and Trends in Industrialized Countries, 2011: A Statistical Overview, at 16(Figures 5 \& 6), available at http://www.unhcr.org/4e9beaa19.html (last visited on Aug. 18, 2013).

94 See Court Grants Refugee Status to Korean-Chinese who Help North Korean Defectors, YonHap News (Feb. 20, 2011), available at $\mathrm{http} / /$ english.yonhapnews.co.kr/national/2011/02/20/78/0301000000AEN201102200006003 20F.html; Tae Woo Park, Ethnic Korean from China Granted Refugee Status, HANKYoren DaILY (Aug. 23, 2012), available at http://www.hani.co.kr/arti/english_edition/e_international/548368.html (all last visited on Oct. 27, 2013). Similar reports have speculated that Japan is reluctant to recognize Chinese nationals as refugees because of diplomatic considerations. See also Osamu Arakaki, Refugee Law and Practice in Japan 31 (2008).

95 Supra note 37, $\uparrow$ 4; Byoung Hyun Cho, Refugee Protection in Korea Judiciary, Paper presented at $9^{\text {th }}$ International Association of Refugee Law Judges Conference 3 (Sept. 8, 2011), available at http://www.iarlj.org/general/images/ stories/BLED_conference/papers/08._Bled_2011.pdf (last visited on Aug. 18, 2013).

96 Supra note $37, \boldsymbol{\top} 11$. 


\section{Conclusion}

As this essay demonstrates, the new Korean Refugee Act is not perfect. There are certain elements that are inconsistent with international legal standard contained in the Refugee Convention and international human rights treaties. There are also important questions relating to implementation that remain to be answered. In the coming years, it will be important for the increasingly active Korean civil society organizations involved in refugee issues to maintain pressure on the government to follow through on its international commitments.

Nevertheless, it is worth stressing that the Refugee Act represents a major improvement over the current framework. When taken together with other developments of the past few years, moreover, it represents a welcome new engagement with the international refugee regime. In a region where relatively few nations have ratified the Refugee Convention, and even fewer comply with it, the positive example of engagement by a regional peer should not be downplayed. While such a development could not have been foreseen five years ago, one can now legitimately point to the Refugee Act as evidence of Korea showing leadership on refugee issues and progressing towards a coherent refugee policy that is largely, although not entirely, consistent with its international obligations. 
